\title{
PROSPEK PENGEMBANGAN KOMODITAS PERKEBUNAN DI WILAYAH BOLIYOHUTO KABUPATEN GORONTALO
}

\author{
Plantation Commodities Development Prospect in Boliyohuto District, \\ Gorontalo Region
}

\author{
Rival Rahman ${ }^{1}$, Dwi Putro Tedjo Baskoro ${ }^{1}$, Boedi Tjahjono ${ }^{1}$
}

Diterima: 13 Agustus 2015

Disetujui: 15 Oktober 2015

\begin{abstract}
Abstrak: Perencanaan penggunaan lahan pertanian sangat penting untuk suatu wilayah dalam mengembangkan komoditas pertaniannya. Wilayah boliyohuto merupakan wilayah yang memiliki potensi sumberdaya lahan yang sangat besar terutama untuk pengembangan komoditas pertanian. Tujuan dari penelitian ini adalah untuk melihat bagaimana prospek pengembangan komoditas perkebunan di wilayah Boliyohuto berdasarkan perkembangan ekonomi komoditas serta sumberdaya fisik lahan. Metode analisis data yang digunakan adalah Interpretasi citra, Location Quotient (LQ) dan Shift Share Analysis (SSA) untuk mengetahui komoditas unggulan serta Analisis Kesesuaian Lahan. Hasil analisis menunjukkan luasan yang berpotensi untuk pegembangan komoditas unggulan adalah seluas 24.655 ha. Kemudian komoditas perkebunan yang menjadi unggulan di Wilayah ini adalah kelapa, kopi, kakao dan kapuk. Berdasarkan hasil analsisi kesesuaian lahan, kelas kesesuaian lahan untuk masing-masing komoditas adala cukup sesuai (S2), sesuai margina (S3), dan tidak sesuai (N). Dari hasil tersebut, prospek pengembangan komoditas perkebunan di Wilayah Boliyohuto meliputi, potensi pengembangan kelapa seluas 16.133,44 ha, kopi seluas 13.159,41 ha, dan komoditas kakao seluas 13.543,94 ha.
\end{abstract}

\section{Kata Kunci : Komoditas perkebuanan, LQ dan SSA, Kesesuaian Lahan}

\begin{abstract}
Agricultural land use planning is essential for a region in developing their agricultural commodities. Boliyohuto region is a region which has the potential for very large land resources, especially for the development of agricultural commodities. The purpose of this study was to see how the development prospects of plantation commodities in the commodity Boliyohuto based economic development as well as physical resources of land. Data analysis method used is the image interpretation, Location Quotient (LQ) and Shift Share Analysis (SSA) to determine the main commodity and Land Suitability Analysis.The analysis showed the extent of the potential for development of superior commodities is an area of 24.655 ha. Then seeded commodities in this region are coconut, coffee, cocoa and cotton. Based on the results analsisi land suitability, land suitability classes for each commodity is moderately suitable (S2), marginally suitable (S3), and is not suitable $(\mathrm{N})$. From these results, the prospects for the development of plantation commodities in the region Boliyohuto covers, palm development potential area of 16133.44 hectares, an area of 13159.41 ha of coffee, and cocoa area of 13543.94 ha.
\end{abstract}

Keywords :Plantationcommodities, LQandSSA, Land Suitability

\footnotetext{
${ }^{1}$ Program Studi Ilmu Perencanaan Wilayah, Sekolah Pascasarjana IPB
}

Korespondensi: rival_rahman68@yahoo.com 


\section{PENDAHULUAN}

Lahan merupakan salah satu aspek yang sangat penting di muka bumi ini. dimana lahan itu sendiri adalah modal utama manusia dalam memenuhi kebutuhan hidupnya. Akan tetapi keberadaan lahan itu sendiri mulai terancam seiring berkembangnya zaman dari waktu kewaktu terutama untuk lahan-lahan pertanian. Untuk itu pemanfaatan lahan secara lestari dan baik sangat diperlukan untuk meningkatkan produktivitas lahan itu sendiri sehingga bisa membantu dalam pengembangan wilayah utamanya dari sektor pertanian.

Kabupaten Gorontalo merupakan kabupaten yang terluas di Provinsi Gorontalo dengan jumlah penduduk yang paling banyak di antara kabupaten-kabupaten lainnya. BPS 2013 mencatat bahwa jumlah penduduk Kabupaten Gorontalo adalah 368.053 jiwa dengan tingkat pertumbuhan penduduk $1,18 \%$. dengan luas kabupaten $2.207,58 \mathrm{~km} 2$. kabupaten ini memiliki potensi sumberdaya alam yang cukup besarsalah satunya dalam hal potensi pertanian. Kabupaten ini di kenal sebagai salah satu kabupaten yang sangat berkontribusi dalam hal produksi pertanian, hal ini dibuktikan dengan kontribusi sektor pertanian adalah yang terbesar ke dua setelah sektor jasa terhadap perekonomian Kabupaten Gorontalo.

Dari segi potesi lahannya kabupaten ini sudah jelas memiliki potensi lahan yang cukup besar dari luas kabupaten yaitu $2.207,58 \mathrm{~km}^{2}$. potensi lahan yang ada tersebar di seluruh Wilayah kabupaten inisalah satunya terdapat di Wilayah Boliyohuto. Wilayah ini berada dilima kecamatan yaitu Kecamatan Mootilango, Asparaga, Tolangohula, Boliyohuto dan Kecamatan Bilato. Wilayah ini dikenal sebagai sentra produksi pertaniannya salah satunya adalah produksi komoditas perkebunan.

Potensi pertanian diwilayah ini memang cukup besar akan tetapi belum diikuti oleh meningkatnya hasilnya. Hal ini disebabkan oleh pengembangan pertaniannya tidak disertai dengan perencanaan yang baik. Sehingga hasil yang didapatkanpun tidak maksimal. Disamping itu kebijakan pemerintah yang lebih berkonsentrasi kepada komoditas pangan terutama jagung membuat komoditas perkebunan sudah tidak menjadi pilihan petani sebagai komoditas yang dikembangkan. Padahal komoditas perebunan menjadi salah satu alternatif komoditas yang bisa dikembangkan terutama di lahan-lahan yang berlereng miring yang tidak bisa dikembangkan tanaman jagung.

Demi mingkatkan kembali produksi perkebunan di wilayah ini perlu adanya satu terobosan untuk melihat bagaimana potensi pengembangan komoditas perkebunan di wilayah ini. Salah satu cara yang dilakukan adalah menganalisis potensi lahan untuk pengembangan komoditas perkebunan. Salah satu analsisi yang dapat dilakukan adalah analsisi komoditas unggulan berdasarkan nilai LQ dan SSA serta analsisi kesesuaian lahan.

Dimana analisis LQ dan SSA merupakan suatu analisis komoditas unggulan yang dinilai berdasarkan perspektif ekonomi sederhana, seperti yang dijelakan olehRizkian Azwartika dan Sardjito (2013)yang menjelaskan bahwa LQ merupakan suatu alat pengembangan ekonomi yang lebih sederhana dengan segala kelebihan dan keterbatasannyaserta metode ini merupakan metode yang umum digunakandalam model ekonomi basis sebagai langkah awal untukmemahami sektor kegiatan yang menjadi pemicupertumbuhan. sedangkan analsisi kesesuaian lahan merupakan analisis berdasarkan potensi sumberdaya fisik lahannya. Evaluasi sumberdaya adalah membandingkan persyaratan yang diperlukan oleh tipe penggunaan lahan yang akan diteraapkan dengan sifat-sifat atau kualitas lahan yang dimiliki oleh lahan yang akan diterapkan dengaan sifatsifat atau kualitas lahan yang dimiliki oleh lahan yang akan digunakan. Dengan demikian akan diketahui potensi lahan atau kelas kesesuaian lahan dari suatu wilayah (Sitorus, 2004; Hardjowigeno dan Widiatmaka 2007). Sehingga dengan analsisi ini dapat di dapatakan suatu rekomendasi pengembangan komoditas perkebuanan diwilayah Boliyohuto Kabupaten Gorontalo. 
Tujuan dari penelitian ini adalah untuk mengetahui prospek pengembangan komoditas perkebunan di Wilayah Bolyohuto Kabupaten Gorontalo.

Penelitian dilakukan di Wilayah Boliyohuto Kabupaten Gorontalo yang terdiri dari 5 kecamatan yaitu kecamatan Boliyohuto, Asparaga, Tolangohula Mootilango dan Kecamatan Bilato seperti yang terlihat pada Gambar 1.

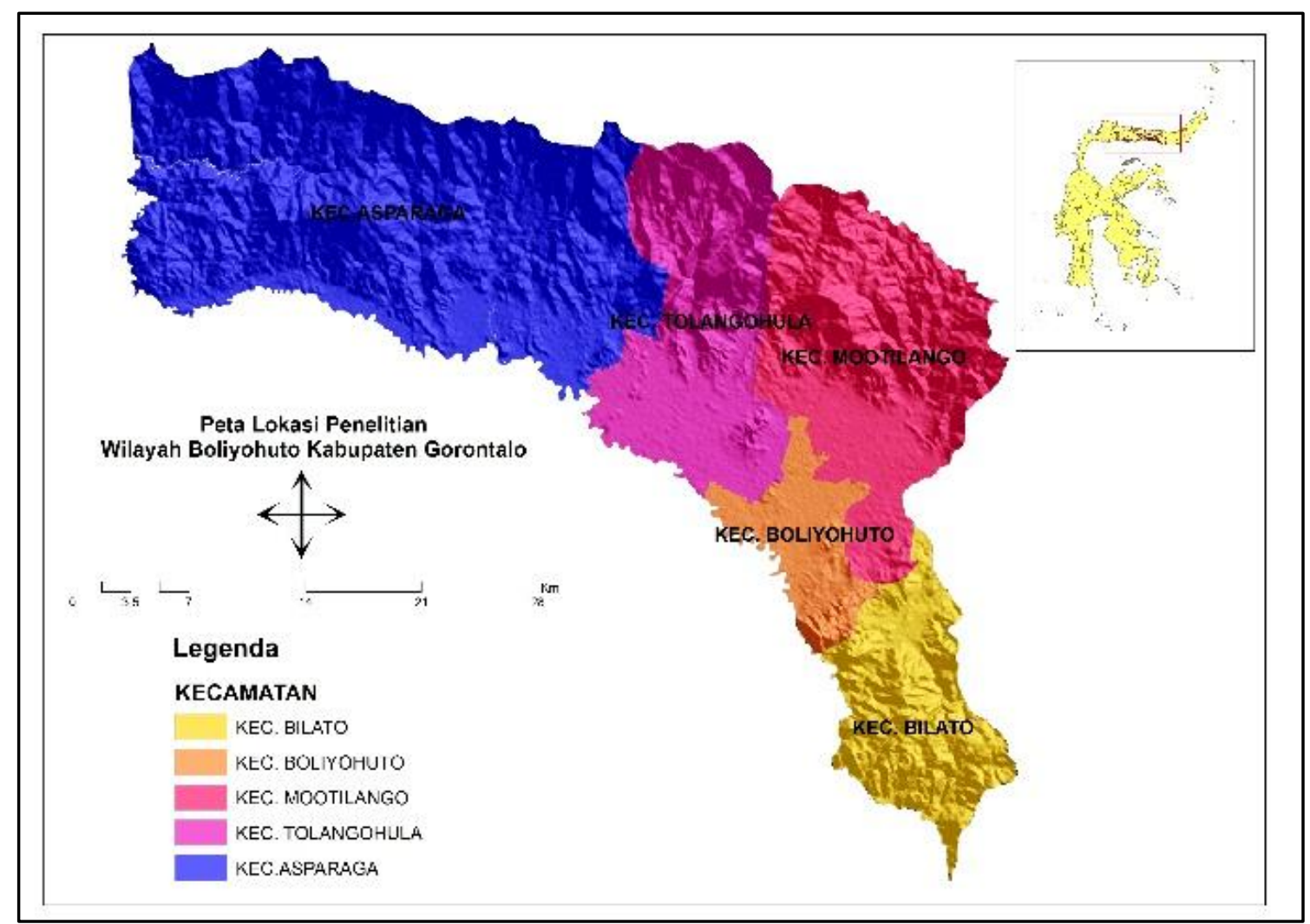

Gambar 1. Peta Lokasi Penelitian

\section{METODE ANALISIS DATA}

Data-data digunakan dalam penelitian ini bersumber dari data primer dan data sekunder. Data primer diperoleh dari survei langsung ke lapangan baik melalui wawancara maupun pengamatan langsung di lapangan. Data sekunder yang digunakan adalah luas panen dan produksi komoditas pertanian Kabupaten Gorontalo tahun 2013, data curah hujan, peta topografi, peta administrasi kabupaten, peta lereng dan elevasi, peta RTRW Kabupaten, peta penggunaan lahan, peta tanah yang bersumber dari hasil inventarisasi dan penelusuran data baik pada buku, peta, internet, perundang-undangan, penelitian terdahulu, maupun dari beberapa instansi terkait, baik instansi pemerintah di daerah maupun pusat, atau instansi/lembaga independen lainnya.

\section{Potensi Ketersediaan lahan}

Analisis ketersediaan lahan dilakukan dengan menginterpretasi tutupan lahan melalui citra satelit Wilayah Boliyohuto yang di kombinasikan dengan peta penggunaan lahan RTRW Kabupaten Gorontalo serta peta kawsan hutan Provinsi Gorontalo. Sehingga dengan 
analsis tersebut dapat dilihat sejauh mana potensi ketersediaan lahan untuk pengembangan komoditas perkebunan di Wilayah Boliyohuto.

\section{Location Quotient (LQ)}

Location Quotient Analysis menurut Blakely (1994) dalam Rustiadi et al. (2011)didefinisikan sebagai rasio persentase dari total aktivitas pada subwilayah ke-i terhadap persentase aktivitas total wilayah yang diamati. Secara umum, metode analisis ini digunakan untuk menunjukkan lokasi pemusatan/basis (aktifitas). Asumsi yang digunakan dalam analisis ini adalah: (1) kondisi geografis relative seragam; (2) pola-pola aktivitas bersifat seragam; (3) setiap aktivitas menghasilkan produk yang sama. Rumus matematis dari analisis pembagian lokasi adalah sebagai berikut:

Dimana

$$
L Q i j=\frac{X i j / X i}{X . j / /_{X . .}}
$$

LQij = Nilai aktivitas ke $\mathrm{j}$ pada unit wilayah $\mathrm{j}$

$\mathrm{Xi} \quad=$ Jumlah seluruh aktivitas di unit wilayah ke-i

$\mathrm{Xj} \quad=$ Jumlah aktivitas ke $\mathrm{j}$ di seluruh unit wilayah

$\mathrm{X} \ldots=$ = Besaran aktivitas total diseluruh unit wilayah

\section{Shift Share Analysis (SSA)}

Shift share analysis merupakan salah satu dari sekian banyak teknik analisis untuk memahami pergeseran struktur aktivitas di suatu lokasi tertentu dibandingkan dengan suatu referensi (dengan cakupan wilayah lebih luas) dalam dua titik waktu. Dari hasil analisis SSA akan diperoleh gambaran kinerja aktivitas di suatu wilayah. Gambaran kinerja ini dapat dijelaskan dari 3 komponen hasil analisis (Rustiadi et. al 2011):, yaitu Komponen Laju Pertumbuhan Total (komponen share), Komponen Pergeseran Proporsional (komponen proportional shift), dan Komponen Pergeseran Diferensial (komponen differential shift). Persamaan analisis SSA adalah sebagai berikut:

a

$$
S S A=\left(\frac{X . .(t 1)}{X . .(t o)}-1\right)+\left(\frac{X i(t 1)}{X i(t 0)}-\frac{X . .(t 1)}{X . .(t 0)}\right)+\left(\frac{X i j(t 1)}{X i j(t 0)}-\frac{X i(t 1)}{X i(t 0)}\right)
$$

Dimana:

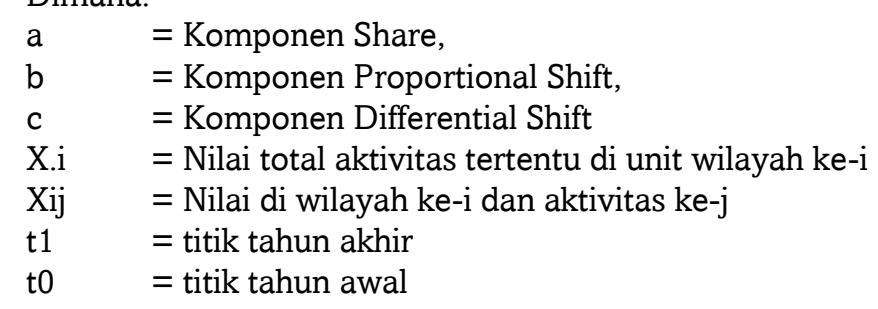

\section{Analisis Kesesuaian Lahan}

Analisis kesesuaian lahan dilakukan melalui evaluasi lahan setelah komoditas unggulan tanaman ditentukan. Komoditas-komoditas unggulan yang telah didapatkan dari hasil analisis LQ dan SSA tadi akan di lihat bagaimana kesesuaiannya terhadap kondisi dilapangan. Sehingga akan didapatkan sebaran lahan yang sesuai untuk masing-masing komoditas. Evaluasi kesesuaian lahan dilakukan dengan menggunakan metode FAO (1976) 
yang dimodifikasi oleh balai besar Sumberdaya Lahan Nasional. Metode ini dilakukan dengan membandingkan karakteristik lahan/kualitas lahan dengan dengan kriteria kesesuaian lahan komoditas unggulan terpilih.

\section{Arahan Pengembangan komoditas Perkebunan}

Setelah dilakukan analsis Komoditas unggulan dan kesesuaian lahan maka selanjutnya dilakuakan analsisi arahan peruntukan lahan komoditas perkebunan. Arahan pengembangan komoditas ini dilihat berdasarkan hasil penggabungan antara komoditas unggulan di wilayah boliyohuto berdasarkan nilai LQ dan SSA, penilaian kesesuaian lahan, ketersediaan lahan melalui peta penggunaan lahan Wilayah Boliyohuto Kabupaten Gorontalo. Sehingga dengan hasil ini dapat dilihat mana lahan-lahan yang potensi untuk pengembangan komoditas perkebunan dan juga lahan-lahan yang sesuai untuk pengembangan komoditas perkebunan di wilayah Boliyohuto Kabupaten Gorontalo.

\section{HASIL DAN PEMBAHASAN}

\section{Potensi Ketersediaan Lahan}

Lahan-lahan yang dianggap potensial untuk pengembangan komoditas perkebunan ini merupakan lahan yang tersedia di luar dari kawasan lindung, kawasan suaka alam, sempadan sungai serta lahan sawah. Penilaian ini di pakai sebagai landasan penentuan daya dukung yang diamanatkan di peraturan tata ruang. Berdasarkan hasil interpretasi citra satelit Lansat-8 yang di overlay dengan peta penggunaan lahan RTRW Kabupaten Gorontalo dan peta kawasan hutan provinsi Gorontalo, lahan-lahan yang berpotensi dan dapat dijadikan lahan pengembangan komoditas perkebunan dapat dilihat pada tabel 1 dan Gambar 2.

Tabel 1. Potensi Pengembangan Komoditas Unggulan wilayah Boliyohuto Kabupaten Gorontalo

\begin{tabular}{lll}
\hline Penggunaan Lahan & Luas (ha) & $\%$ \\
\hline Hutan Lindung & 1289,5 & 1,31 \\
Hutan Produksi Dapat Dikonversi & 1062,4 & 1,08 \\
Hutan Produksi Terbatas & 17321,1 & 17,55 \\
Hutan Produksi Tetap & 15287,4 & 15,49 \\
Kawasan Suaka Alam & 24519,1 & 24,85 \\
Pemukiman & 1391,2 & 1,41 \\
Perkebunan & 4802,9 & 4,87 \\
Sawah & 13145,2 & 13,32 \\
Semak Belukar & 7412,9 & 7,51 \\
Tegalan & 12438,4 & 12,61 \\
Jumlah & 98670,2 & 100 \\
\hline
\end{tabular}

Dari tabel diatas dapat dijelaskan bahwa potensi pengembangan komoditas perkebunan di wilayah boliyohuto sangat besar. Ini dibuktikan dengan luas lahan yang dapat dikembangkan masih sangat besar seperti semak belukar dan tegalan masing-masing 7.412,94 ha dan 12.438,36, kemudian untuk kawasan perkebunan itu sendiri seluas 4802,93 ha. Belum lagi kawasan hutan produksi sangat besar potensi jka dikembangkan yaitu seluas 33670,87 ha. Hal ini memperlihatan bahwa prospek pengembangan komoditas unggulan dari segi ketersediaan lahan sangatlah besar. 


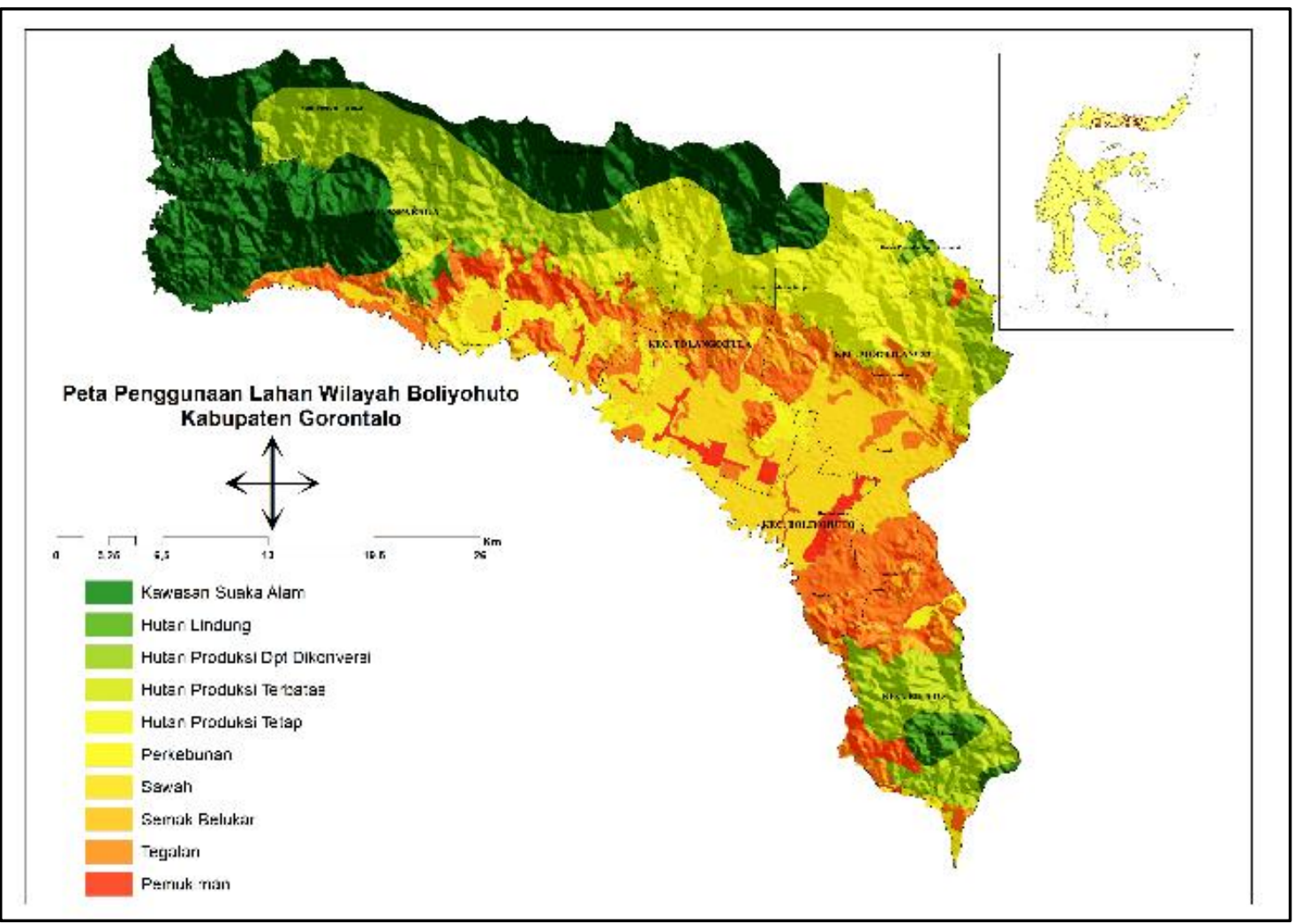

Gambar 2. Peta Penggunaan Lahan Wilayah Boliyohuto Kabupaten gorontalo

\section{Komoditas Unggulan Perkebunan}

\section{LQ Sektor Perkebunan}

Analsis Location Questient (LQ) merupakan suatu analisis yang digunakan untuk mengetahui spesialisasi kegiatan perekonomian atau mengkur konsentrasi relatif kegiatan ekonomi untuk mendapatkan gambaran penetapan sektor unggulan sebagai leading sector suatu kegiatan ekonomi (Hendrayana 2003).Sejalan dengan pernyataan tesebut Kadariah (1985)dalam Yuliyanti (2011) menjelaskan bahwa metode Analisis (LQ) bertujuan untuk mengidentifikasi suatu komoditas yang ada pada suatu wilayah apakah termasuk ke dalam suatu basis atau non basis.Dengan kata lain, nilai LQ akan memberikan indikasi kemampuan suatu daerah dalam menghasilkan suatu komoditas, apakah mempunyai potensi untuk menyuplai daerah lain, mendatangkan dari daerah lain, atau dalam keadaan seimbang.

Data yang digunaan untuk menghitung nilai LQ dari komoditas perkebunan ini adalah data rata-rata luas panen tanaman perkebunan tahun 2012 dan 2013 yang besumber dari badan pusat statistik kabupaten gorontalo tahun 2013 dan 2014. Tanaman perkebunan yang dianalisis ini berjumlah 4 komoditas yang merupakan komoditas yang dikembangkan oleh masyarakat setempat.

Dari hasil analsis LQ yang telah dilakukan dapat dijelaskan bahwa komoditas perkebunan yang menjadi komoditas unggulan yang paling tinggi adalah tanaman kakao. Sebab dari ke-4 komoditas yang dianalsis tanaman kakao yang memiliki pemusatan di tiga kecamatan berbeda yaitu di Kecamatan Asparaga, Bilato dan Kecamatan Tolangohula. Kemudian tanaman kopi dan kelapa memiliki pemusatan didua Kecamatan yang berbeda 
yaitu di kecamatan Boliyohuto dan Mootilango untuk tanaman kakao dan Kecamatan Asparaga dan Mootilango untuk tanaman kelapa. Sedangkan untuk tanaman kapuk pemusatannya ada di kecamatan Boliyohuto.

Dapat dijelaskan juga bahwa hampir seluruh kecamatan mimiliki pemusatan aktivitas komoditas lebih dari satu komoditas yaitu Kecamatan Boliyohuto, Asparaga dan Kecamatan Mootilango. Sedangkan untuk kecaman bilato dan tolangohula hanya memiliki satu komoditas yang berpusat di kecamatan tersebut. Untuk lebih jelasnya dpat dilihat pada Tabel 2.

\section{Shift Share Analysis (SSA)}

Alat Analisis Shift Share digunakan untuk mengetahui kinerja perekonomian wilayah yang direfleksikan dalam bentuk pertumbuhan wilayah, kecepatan pertumbuhan relatif sektor-sektor wilayah, dan daya saing sektor-sektor wilayah. (Bendavid-Val, 1991:67, Amien 1996:106 dalam Harun dan canon 2006). Data yang digunakan dalam melakukan analisis ini adalah data luas panen. Pada penilaian hasil SSA dilihat berdasarkan beberapa nilai analsis diantaranya nilai regional share (RS), propotional shift (PS), dan differensial shift (DS).

Tabel 2. Hasil Perhitungan LQ Tanaman Perkebunan

\begin{tabular}{lllll}
\hline Kecamatan & Kapuk & Kelapa & Kopi & Kakao \\
\hline Boliyohuto & 4,53 & 0,97 & 1,71 & 0,82 \\
Asparaga & 0,00 & 1,02 & 0,00 & 1,08 \\
Bilato & 0,00 & 0,00 & 0,00 & 5,62 \\
Mootliango & 0,00 & 1,05 & 1,50 & 0,79 \\
Tolangohula & 0,00 & 0,95 & 0,56 & 1,31 \\
\hline
\end{tabular}

Dari hasil analsisis dilihat dari Komponen RS menunjukkan bahwa komoditas perkebunan di wilayah Boliyohutopengembanganya mengalami pertumbuhan. Ini dibuktikan dengan nilai komponen analisis regional share (RS) mengarah ke nilai positif $(0,3)$. Hal iini berari komoditas perkebunan di wilayah ini dari waktu ke waktu mengaami peningkatan dari segi produksi diliat berdasaran luas panen.

Setelah itu Dari perkembangan semua komoditas secara keseluruhan kemudian dinilai pertumbuhan untuk tiap komoditas. Hal ini dinilai bedasarkan nilai propotional shift (PS), dimana nilai PS ini menunnjukan pertumbuhan tiap komoditas dengan total perkembangan komoditas secara keseluruahan. Jika hasil dari PS $>0$ maka komoditas tersebut mengalami pertumbuhan, sebaliknya jika hasil PS $<0$ maka komoditas tersebut tidak mengalami pertumbuhan. Hasil analisis menunjukkan bahwa untuk tanaman perkebuanan, komoditas yang mengalami pertumbuhan adalah tanman kapuk, kopi dan kakao sedangkan kelapa tidak mengalami pertumbuhan.

Setelah komponen RS dan PS analisis selanjutnya adalah komonen differensial shift (DS). Dimana komponen DS ini merupakan komponen yang menunjukkan tingakat kompetisi (compotitiveness) satu sektor terhadap sektor lain dalam suatu wilayah. Hal ini sejalan dengan pernyataan Widiatmaka (2013) bahwa differen shift merupakan ukuran yang dapat dijadikan sebagai indikator tingkat kompetisi (compotitiveness) suatu sektor/aktifitas tertentu dibandingkan pertumbuhan total sektor/aktifitas tertentu dalam suatu wilayah. Hasil analisis DS untuk komoditas perkebunan kelapa memiliki tingkat kompetisi paling tinggi ( $\mathrm{DS}=0,3)$ dibandingkan komoditas yang lain di kecamatan boliyohuto. komoditas kakao memiliki tingkat kompetisi paling tinggi di kecamatan asparaga (DS=0,2)dan urutan kedua di Kecamatan Bilato (DS=0,1). Sementara Disisi lain ada juga komoditas yang tidak memiliki tingkat kompetisi yaitu dengan nilai DS $<0$ adalah komoditas kapuk dan kopi. 
Secara keseluruhan analisis yang telah dilakukan sebelumnya yaitu analisis regional share (RS), propotional shift (PS), dan differensial shift (DS) jika dijumlahkan maka akan didapatkan satu komponen yaitu komponen pertumbuhan secara keseluruhan di setiap kecamatan untuk masing-masing komoditas yaitu komponen Shift Share Analysis (SSA). Komponen ini akan melihat komoditas mana yang mengalami pertumbuhan. Suatu komoditas dikatakan mengalami pertumbuhan jika memiliki nilai SSA >0 (+). Dari hasil analisis SSA menunjukkan bahwa komoditas yang mengalami pertumbuhan dengan nilai SSA $>0(+)$ adalah kapuk, kelapa kopi kakao. Ini menunnjukkan bahwa keempat komoditas perkebunan yang ada di wilayah Boliyohuto merupaan komoditas unggulan. Selengkapnya untuk hasil analisis shift share dapat dilihat pada Tabel 3.

\section{Kesesuaian Lahan Komoditas Unggulan Perkebunan}

Dari hasil analsis LQ dan SSA di dapatkan komoditas unggulan perkebunan pada tiap-tiap kecamatan diwilayah Boliyohuto Kabupaten Gorontalo. Sehingga dari segi hasil pertanian berupa luas lahan, luas tanam, luas panen dan Produksi komoditas perkebunan tersebut dianggap memiliki potensi yang besar dan berkembang dari waktu kewaktu. Namun dari hasil tersebut keunggulan ini tidak membuat komoditas ini dianggap unggul secara keseluruhan. Beberapa aspek perlu diperhatikan lagi agar komoditas-komiditas ini kedepan dapat di kembangkan lebih besar lagi, salah satunya adalah aspek kesesuaian lahan.

Tabel 3. Hasil Perhitungan Komponen SSA Tanaman Perkebunan

\begin{tabular}{llllll}
\hline RS & 0,329 & & & & \\
& & & & & \\
PS & & Kapuk & Kelapa & Kopi & Kakao \\
& & 0,248 & $-0,05$ & 0,248 & 0,224 \\
\hline \multirow{4}{*}{ DS } & Kecamatan & Kapuk & Kelapa & Kopi & Kakao \\
& Boliyohuto & 0 & 0,3 & 0 & 0 \\
& Asparaga & 0 & $-0,1$ & 0 & 0,2 \\
& Bilato & 0 & 0 & 0 & 0,1 \\
& Mootliango & 0 & $-0,1$ & 0 & $-0,2$ \\
& Tolangohula & 0 & $-0,1$ & 0 & 0 \\
& Kecamatan & Kapuk & Kelapa & Kopi & Kakao \\
& Boliyohuto & 0,6 & 0,6 & 0,6 & 0,5 \\
SSA & Asparaga & 0,6 & 0,2 & 0,6 & 0,7 \\
& Bilato & 0,6 & 0,3 & 0,6 & 0,6 \\
& Mootliango & 0,6 & 0,2 & 0,6 & 0,3 \\
& Tolangohula & 0,6 & 0,2 & 0,6 & 0,5 \\
\hline
\end{tabular}

Menurut Hardjowigeno (2010) bahwa kesesuaian lahan adalah potensi lahan yang didasarkan atas kesesuaian lahan untuk penggunaan pertanian secara lebih khusus. Untuk itu perlu adanya penilaian kesesuaian lahan sehingga dapat diketahui seberapa potensinya komoditas-komoditas unggulan tersebut dari aspek lahan. Dengan hasil tersebut maka perencanaan koomoditas unggulan akan sesuai dengan daya dukung lahan. Evaluasi dilakukan dengan membandingkan karakteristik lahan dengan kriteria kesesuaian lahan dan menggunakan metode FAO (1976) yang dimodifikasi oleh balai besar Sumberdaya Lahan Nasional. Karakteristik lahan dihasilkan dari hasil analsisi overlay peta tanah satuan lahan 
Provinsi Gorontalo dengan peta peta sumberdaya tanah semi detil Wilayah Paguyaman. Adapun penilaian kesesuain lahan untuk komoditas unggulan Perkebunan ditiap kecamatan adalah sebagai berikut :

\section{Kelapa}

Analisis kesesuaian lahan untuk tanaman perkebuanan kelapa dilakukan di tiga kecamatan di wilayah Boliyohuto yaitu di kecamatan Asparaga Mootilango dan Kecamatan Tolangohula dimana di tiga Kecamatan ini kelapa merupakan komoditas unggulan. Hasil analisis kesesuaian lahan menunjukkan di Kecamatan Asparaga memiliki tiga kelas kesesuaian lahan yaitu kelas kesesuaian lahan (S2) seluas 8.832,41 ha atau 20,52\%, kelas kesesuaian lahan (S3) seluas 7.519 ha atau $17,47 \%$, dan kelas kesesuaian lahan (N) seluas 26.563,36 ha atau 61,72 \% dari total luas wilayah Kecamatan Asparaga. Kemudian di Kecamatan Mootilango hasil kesesuaian lahan menunjukkan tiga kelas kesesuaian lahan juga yaitu (S2) seluas 10.166,25 ha atau 48,06 \%, kelas kelas kesesuaian lahan (S3) seluas $5.151,12$ ha atau $24,35 \%$ dan kelas kesesuaian lahan (N) seluas 5.818,95 ha atau 27,51\%, sedangkan pada kecamatan Tolangohula, kelas kesesuaian lahan untuk tanaman kelapa juga ada tiga kelas yaitu (S2) seluas $8.864,06$ atau $51,60 \%$, kelas kesesuaian lahan (S3) seluas 2054,77 atau 11,96 dan kelas kesesuaian lahan (N) seluas 5.630,54 atau 32,77\% dari total luas wilayah Kecamatan Tolangohula. Selengkapnya untuk sebaran luas kelas kesesuaian lahan tanaman kelapa dapat dilihat pada tabel 4 dan Gambar 3

Tabel 4. Sebaran Luas Kelas Kesesuaian Lahan Tanaman Kelapa

\begin{tabular}{llll}
\hline \multirow{2}{*}{ Kecamatan } & Kelas & Luas & $\%$ \\
& Kesesuaian & & \\
\hline \multirow{3}{*}{ Asparaga } & S2 & 8832,42 & 20,52 \\
& S3 & 7519,27 & 17,47 \\
Jumlah & $\mathrm{N}$ & 26563,4 & 61,72 \\
& Pemukiman & 124,45 & 0,29 \\
Mootilango & & 43039,5 & 100 \\
& S2 & 10166,2 & 48,06 \\
Jumlah & N & 5151,12 & 24,35 \\
& Pemukiman & 16,52 & 27,51 \\
Tolangohula & & 21152,8 & 0,08 \\
& S2 & 8864,05 & 100 \\
Jumlah & $\mathrm{N} 31,61$ \\
\hline
\end{tabular}

\section{Kakao}

Analisis kesesuaina lahan untuk tanaman perkebuanan kakao dilakukan di tiga kecamatan di wilayah Boliyohuto yaitu di kecamatan Asparaga, Bilato dan Kecamatan Tolangohula dimana di tiga kecamatan ini kakao merupakan komoditas unggulan. Hasil analisis kesesuaian lahan menunjukkan di kecamatan Asparaga memiliki dua kelas kesesuaian lahan yaitu kelas kesesuaian lahan (S3) seluas 16.351,69 ha atau 37,99 \%, dan kelas kesesuaian lahan $(\mathrm{N})$ seluas $26.563,36$ ha atau $61,72 \%$ dari total luas wilayah kecamatan Asparaga. Kemudian dikecamatan Bilato hasil kesesuaian lahan menunnjukkan dua kelas kesesuaian lahan juga yaitu kelas kesesuaian lahan (S3) seluas 4.448,29 ha atau $39,60 \%$ dan kelas kesesuaian lahan $(\mathrm{N})$ seluas $6.710,30$ ha atau $59,73 \%$, sedangkan pada 
kecamatan Tolangohula, kelas kesesuaian lahan untuk tanaman kelapa juga ada dua kelas yaitu kelas kesesuaian lahan (S3) seluas 10.918,83 atau 63,56 \% dan kelas kesesuaian lahan (N) seluas 5.630,54 atau 32,77 \% dari total luas wilayah kecamatan Asparaga. Selengkapnya untuk sebaran luas kelas kesesuaian lahan tanaman Kelapa dapat dilihat pada Tabel 30.Selengkapnya untuk sebaran luas kelas kesesuaian lahan tanaman kakao dapat dilihat pada Tabel 5 dan Gambar 3.

Tabel 5. Sebaran Luas Kelas Kesesuaian Lahan Tanaman Kakao

\begin{tabular}{llll}
\hline Kecamatan & Kelas Kesesuaian & Luas & $\%$ \\
\hline \multirow{3}{*}{ Asparaga } & S3 & 16351,7 & 37,99 \\
& N & 26563,4 & 61,72 \\
Jumlah & Pemukiman & 124,45 & 0,29 \\
& & 43040 & 100 \\
Bilato & S3 & 4448,29 & 39,61 \\
& $\mathrm{~N}$ & 6710,3 & 59,73 \\
Jumlah & Pemukiman & 75,16 & 0,67 \\
& & 11233,8 & 100 \\
Tolangohula & S3 & 10918,8 & 63,55 \\
& Pemukiman & 5630,54 & 32,77 \\
Jumlah & & 630,64 & 3,67 \\
\hline
\end{tabular}

Kopi

Analisis kesesuaian lahan untuk tanaman kopi dilakukan di dua kecamatan di wilayah Boliyohuto yaitu di kecamatan Boliyohuto dan Tolangohula dimana di dua kecamatan ini kopi merupakan komoditas unggulan. Hasil analisis kesesuaian lahan menunjukkan di kecamatan Boliyohuto hanya ada satu kelas kelas kesesuaian lahan yaitu (S3) seluas 5.516,63 ha atau 91,02 \%, dari total luas wilayah kecamatan Boliyohuto. Kemudian dikecamatan tolangohula hasil kesesuaian lahan menunnjukkan dua kelas kesesuaian lahan juga yaitu kelas kesesuaian lahan (S3) seluas 10.918,83 ha atau 63,56 \% dan kelas kesesuaian lahan (N) seluas 5.630,4 ha atau 32,77\% dari total luas wilayah kecamatan Tolangohula. Selengkapnya untuk sebaran luas kelas kesesuaian lahan tanaman kopi dapat dilihat pada Tabel 5 dan Gambar 3.

Tabel 5. Sebaran Luas Kelas Kesesuaian Lahan Tanaman kopi

\begin{tabular}{llll}
\hline Kecamatan & Kelas Kesesuaian & Luas & $\%$ \\
\hline \multirow{2}{*}{ Boliyohuto } & S3 & 5516,63 & 91,02 \\
Jumlah & Pemukiman & 544,44 & 8,98 \\
& & 6061,07 & 100 \\
Tolangohula & N & 10918,82 & 63,54 \\
& Pemukiman & 5630,54 & 32,77 \\
Jumlah & & 630,64 & 3,67 \\
\hline
\end{tabular}

\section{Kapuk}

Analisis kesesuaina lahan untuk tanaman kapuk dilakukan di satu kecamatan saja di wilayah Boliyohuto yaitu di kecamatan Boliyohuto dimana di kecamatan ini kapuk merupakan komoditas unggulan. Hasil analisis kesesuaian lahan menunjukkan di kecamatan ini memiliki dua kelas kesesuaian lahan yaitu kelas kesesuaian lahan (S2) seluas 403,08 ha atau 6,65 \%, dan kelas kesesuaian lahan (S3) seluas 5.113,55 ha atau 84,37\% dari total luas wilayah kecamatan tersebut. Selengkapnya untuk sebaran luas kelas kesesuaian lahan tanaman kapuk dapat dilihat pada tabel 6 dan Gambar 3. 
Tabel 6. Sebaran Luas Kelas Kesesuaian Lahan Tanaman Kapuk

\begin{tabular}{llll}
\hline Kecamatan & Kelas Kesesuaian & Luas & $\%$ \\
\hline \multirow{3}{*}{ Boliyohuto } & S2 & 403,08 & 6,65 \\
& S3 & 5113,56 & 84,37 \\
Jumlah & Pemukiman & 544,44 & 8,98 \\
& & 6061,08 & 100 \\
\hline
\end{tabular}

Kelas kesesuaian lahan yang dihasilkan tidak sepenuhnya merupakan kelas kesesuaian lahan yang potensial akan tetapi masih dalam bentuk kelas kesesuaian lahan aktual. Artinya kelas kesesuaian lahan yang ada merupakan kondisi saat ini tanpa ada perlakuan atau tindakan perbaikan sehingga setiap lahan yang dianalsisi masih memiliki berbagai macam faktor pembatas dalam hal potensi lahannya. Hasil analisis kelas kesesuaian lahan perkebunan secara keseluruhan memiliki berbagai macam faktor pembatas baik itu kelas kesesuaian S2, S3 dan N faktor yang membatasi kelas kesesuaian lahan tersebut diantaranya faktor ketersediaan air dalam hal ini curah hujan dan kelembaban (w), ketesediaan unsur hara (n), media perakaran (r) atau tekstur tanah, serta faktor bahaya erosi atau kemiringan lereng (eh).
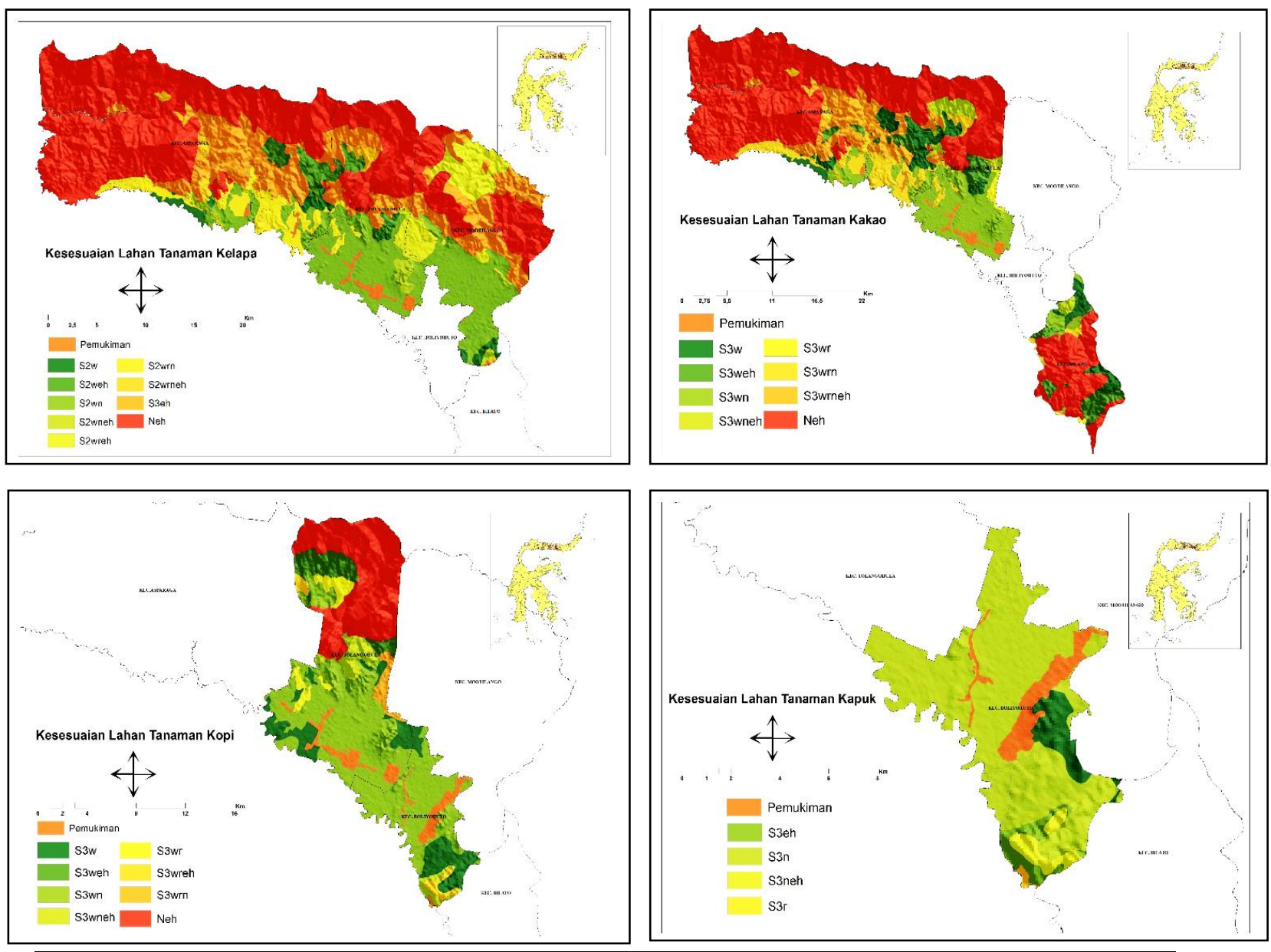

Gambar 3. Peta Kesesuaian Lahan Tanaman Perkebunan Wilayah Boliyohuto 


\section{Prospek Pengembangan Komoditas Perkebunan}

Prospek pengambangan komoditas unggulan perkebunan dilihat berdasarkan beberapa parameter yaitu yang pertama adalah potensi ketersediaan lahan berdasarkan peta penggunaan lahan. Lahan yang dijadikan untuk pengembangan komoditas ungulan merupan lahan yang tidak berada di areal hutan lindung, sempadan sungai dan hutan suaka alam. Areal yang potensial untuk pengembangan komoditas unggulan disesuaikan dengan penggunaan lahan yang memungkinkan untuk pengembangan komoditas unggulan.

Kemudian untuk arahan pengembangan komoditas perkebunan juga dilihat berdasarkan komoditas unggulan di tiap kecamatan yang dilihat berdasarkan nilai LQ dan SSA. Disamping itu arahan pengembangan komoditas unggulan dilihat berdasarkan kelas kesesuaian lahan untuk masing-masing komoditas. Diutamakan untuk kelas kesesuaian lahan yang sesuai S1, S2 dan S3. Dan jika kelas kesesuaian lahannya sama maka keputusan pengembangan komoditas dilihat berdasarkan kebijakan prioritas pengembangan komoditas daerah maupun nasional. Prospek pengembangan komoditas unggulan tanaman perkebunan di Wilayah Boliyohuto dapat dilihat pada Tabel dan Gambar 3.

Tabel 7. Prospek Pengembangan Komoditas Perkebunan Wilayah Boliyohuto

\begin{tabular}{|c|c|c|}
\hline Komositas Perkebunan & Luas & Persentasi \\
\hline Kelapa & 16133,44 & 16,35 \\
\hline Kopi & 13159,41 & 13,34 \\
\hline Kakao & 13543,94 & 13,73 \\
\hline Kapuk & 0 & 0 \\
\hline Jumlah & 42836,79 & 43,42 \\
\hline
\end{tabular}

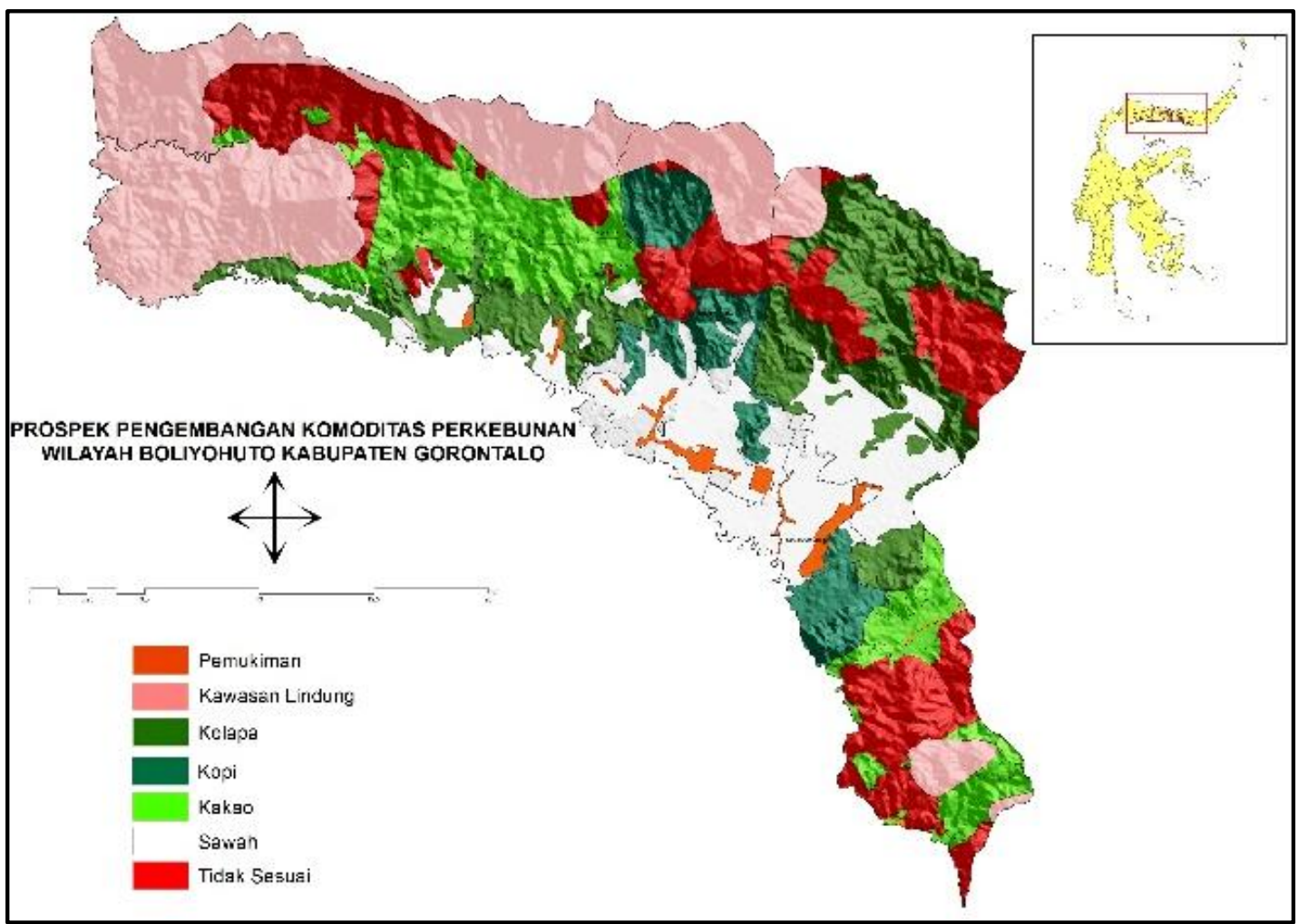

Gambar 4. Peta Sebaran Pengembangan Komoditas Perkebunan Wilayah Boliyohuto 
Berdasarkan tabel dan Gambar diatas dapat dijelaskan bahwa prospek pengembangan komoditas unggulan perkebunan di Wilayah Boliyohuto tersebar hampir di semua wilayah ini dengan pusat pengembangan di masing-masing kecamatan. Diantaranya untuk pegembangan komoditas kelapa berdasarkan hasil analsis LQ, SSA dan kesesuaian lahan prospek pengembangannya tersebar di dua Kecamatan yaitu Kecamatan Mootilango dan Kecamatan Asparaga dengan luas potensi pengembangannya adalah 16.133,44 ha atau $16,35 \%$ dari luas Wilayah Boliyohuto. Kemudian untuk pengembagan komoditas kopi prospek pengembangannya juga di dua kecamatan yaitu Kecamatan Tolangohula dan Kecamatan Boliyohuto dengan luas 13.159,41 ha. Kemudian untuk pengembangan komoditas kakao tersebar di dua kecamatan juga yaitu kecamatan Bilato dan Kecamatan Asparaga dengan luas pengembangan 13.543,94 ha atau $13,73 \%$ dari luas Wilayah Boliyohuto. Sedangkan untuk Komoditas Kapuk tidak memiliki prospek pegembangan walaupun dari nilai LQ dan SSA merupakan komoditas unggulan, namun di wilayah ini komoditas kapuk tidak menjadi komoditas yang dibudidayakan akan tetapi hanya komoditas yng dimanfaatkan hasilnya dari tanaman yang sudah ada tanpa di budidayakan sehingga prospeng komoditas ini dianggap tidak akan bisa berkembang. Disamping tidak ada masyarakat yang mengembangkan juga kriteria dari komoditas ini yang berumur panjang untuk bisa di panen.

\section{KESIMPULAN}

Dari hasil analisis yang telah dilakukan maka dapat disimpulkan bahwa Di wilayah Boliyohuto berdasarkan analsisi LQ dan SSA, yang menjadi komoditas unggulan adalah empat komoditas yaitu kelapa, kopi, kakao, dan kapuk.Hasil analisis kesesuaian lahan untuk komoditas perkebunan memiliki kelas kesesuaian lahan yang cukup sesuai (S2), sesuai marginal (S3) dan ada juga yang tidak sesuai (N). Sehingga dari hasil tersebut menunjukkan bahwa Prospek pengembangan komoditas perkebunan diwilayah Boliyohuto yaitu seluas 16.133,44 ha untuk komoditas kelapa, 13.159,41 ha untuk komoditas kopi, dan 13.543,94 ha untuk komoditas kakao.

\section{DAFTAR PUSTAKA}

Azwartika, R R. dan Sardjito. 2013. Pengembangan Komoditas Unggulan Pertanian dengan Konsep Agribisnis di Kabupaten Pamekasan. Jurnal Teknik Pomits Vol. (2), No. 2, (2013)

[BPS] Badan Pusat Statistik Kabupaten Gorontalo. 2013. Kabupaten Gorontalo dalam Angka. Gorontalo : BPS Kabupaten Gorontalo.

[BPS] Badan Pusat Statistik Kabupaten Gorontalo. 2014. Kabupaten Gorontalo dalam Angka. Gorontalo : BPS Kabupaten Gorontalo.

[FAO]. Food and Agriculture Organization. 1976. A Framework for land evaluation. Rome (IT); Soil Bulletin 32.

Hardjowigeno, S. Widiatmaka. 2007. EvaluasiKesesuaianLahandanPerencanaan Tata GunaLahan. Bogor :GadjahMada University Press

Harun, U. R, dan Canon S. Analisis LQshift LQshare untuk Mengukur Dampak Perluasan Kota terhadap Kinerja Ekonomi Regional. Jurnal Perencanaan Wilayah dan kota. Vol 17 .21:21-40

Hendrayana R. 2003. Aplikasi Metode Location Quotient dalam Penentuan Komoditas Unggulan Nasional. Jurnal Informatika Pertanian Vol. 12: 1-21

Rustiadi E. Saefulhakim S. Panuju D. R. 2011. PerencanaandanPengembangan Wilayah. Jakarta (ID): Cresspent, yayasanObor Indonesia. 
Yulianti, M. 2011. Penentuan Prioritas Komoditas Unggulan Buah-Buahan di Kabupaten Minahasa Utara Provinsi Sulawesi Utara: Aplikasi Analisis LQ dan Daya TarikDaya Saing. Jurnal Agribisnis Perdesaan. Vol. 01 03: 206

Widiatmaka. 2013. Analsisi Sumberdaya Wilayah Untuk Perencanaan Tata Guna Lahan. Program Studi Pengelolaan Sumberdaya Alam dan Lingkungan. Sekolah Pascasarjana Institut Pertanian Bogor. Bogor 